\title{
Identification the Presence of Vibrio Species by TCBS Media in Different Water Samples Collected from Different Locations
}

\author{
Dr. Pawan Kumar ${ }^{1}$, Dr. Uma Shankar ${ }^{2}$, Pushpinder Paul ${ }^{3}$ \\ ${ }^{1}$ Associate Professor, Department of Biotechnology, Singhania University, Rajasthan, India \\ ${ }^{2}$ Consultant Scientist at Cytogene Research and development, Lucknow, Uttar Pradesh, India \\ ${ }^{3}$ Research Scholar, Department of Biotechnology, Singhania University, Rajasthan, India
}

\begin{abstract}
The purpose of this study was to identify the presence of Vibrio species in the water samples collected from different locations of Himachal Pradesh, Gujarat and Uttar Pradesh. About 30 water samples were collected from different locations. Vibrio species were identified by using TCBS agar medium. Sucrose included as a fermentable carbohydrate, with the help pH indictor (Bromothymol blue and Thymol blue indicators) allows in distinguishing bacteria with yellow and green colour colonies on plates. Out of 30 samples, 22 samples showing positive results for Vibrio species. Identification of Vibrio species in different types of aquatic habitats (Sea water, River water, tap water, pond water and Ground water) was done.
\end{abstract}

Keywords: Vibrio, Isolation, TCBS, Water samples

\section{Introduction}

Vibrio is a genus of Gram-negative bacteria that possess a curved rod shape and naturally inhabits aquatic environments worldwide [1-4]. Within the genus Vibrio, several species are known to be important human pathogens [5]. Among these, Vibrio cholerae, Vibrio vulnificus, and Vibrio parahaemolyticus are the major pathogenic Vibrio species. $V$. cholerae and $V$. parahaemolyticus, contracted through consumption of contaminated seafood and seawater, can cause gastroenteritis whereas $V$. vulnificus can cause septicemia by exposure of an open wound to seawater or consumption of contaminated seafood [6].

The genus Vibrio, within the family Vibrionaceae, is a diverse group of Gram-negative bacteria found exclusively in the aquatic environment. Important pathogenic members include Vibrio cholerae, the causative agent of cholera, and Vibrio parahaemolyticus and Vibrio vulnificus, which have been implicated in diarrhea, septicemia, and wound infections [7]. There is several water borne diseases which are highly pathogenic to humans. Among all, Vibrio plays an important role. The most common disease (cholera) caused by Vibrio

TCBS agar is commercially available and easy to prepare, requires no autoclaving, and is highly differential and selective. However, it has a relatively short shelf life once prepared (3 to 5 days) unless plates are carefully protected against drying. TCBS is subject to lot-to-lot and brand-tobrand variations in selectivity, and growth on this medium is not suitable for direct testing with $V$. cholerae $\mathrm{O} 1$ antisera. TCBS agar is green when prepared. Overnight growth (18 to 24 hours) of $V$. cholera will produce large (2 to $4 \mathrm{~mm}$ in diameter), slightly flattened, yellow colonies with opaque centers and translucent peripheries. The yellow color is caused by the fermentation of sucrose in the medium. Sucrose non-fermenting organisms, such as $V$. parahaemolyticus, produce green to blue-green colonies. Suspicious colonies for further testing should be sub-cultured to a non-inhibitory medium, such as gelatin agar, heart infusion agar (HIA), Kligler's iron agar (KIA), or triple sugar iron agar (TSI). [8]

\section{Material and Methods}

\subsection{Collection of Water Sample}

30 samples of water (Salt and Sweet) were collected from different water bodies like Pond Water, River water, Tap Water, etc. from Himachal, Gujarat, and Uttar Pradesh (India).

\subsection{Isolation on TCBS agar medium}

Isolation of 30 strains of Vibrio spp. were done from water samples collected from different environment. It was isolated by using TCBS agar medium. Sucrose included as a fermentable carbohydrate, with the help $\mathrm{pH}$ indictor (Bromothymol blue and Thymol blue indicators) allows in distinguishing bacteria with yellow and green colored colonies on plates. Yellow colonies indicate those Vibrio spp. (Vibrio cholera, Vibrio alginolyticus, Vibrio furnisci, Vibrio mimicus) which ferment sucrose and green color colony (Vibrio parahaemolyticus, Vibrio vulnificus) indicated as a non-sucrose fermenting bacteria. For isolation of Vibrio species $200 \mu$ l of different water sample was taken for spreading onto TCBS (selective media) agar plates using L-shape glass rod and left for incubation for 48 hours incubation period at $37^{\circ} \mathrm{C}$ for development of the Vibrio colonies. 


\section{International Journal of Science and Research (IJSR) \\ ISSN (Online): 2319-7064}

Index Copernicus Value (2013): 6.14 | Impact Factor (2014): 5.611

Table 1: List of water samples

\begin{tabular}{|c|c|c|c|}
\hline S. No & Sample & Location /Address & Location Id \\
\hline 1 & Sea water & Dahej sea port, Disst-Bharuch, Gujarat & SW \\
\hline 2 & Pond water & Disst-Bharuch, Gujarat & PW \\
\hline 3 & River water & Disst-Bharuch, Gujarat & RW \\
\hline 4 & River water & \multirow{2}{*}{ Pung River, Vill-Saud, P.O-Jol Lambri, Tehsil-Sujanpur, Distt.-Hamirpur(H.P) } & PR-1 \\
\hline 5 & River water & & SKTC \\
\hline 6 & River Water & \multirow{3}{*}{ Tehsil-Sujanpur, Distt.-Hamirpur, H.P } & VR \\
\hline 7 & Ground Water (Bawadi) & & BNVR \\
\hline 8 & Ground Water (Naun) & & NNFS \\
\hline 9 & Ground Water (Naun) & Vill-Deenge de gran, P.O-Patlander, Tehsil-Sujanpur, Distt-Hamirpur, H.P. & DDGN \\
\hline 10 & River Water (Pung River) & \multirow{2}{*}{ Vill-Bhugol, P.O-Patlander, Tehsil-Sujanpur, Distt-Hamirpur, H.P. } & PR-2 \\
\hline 11 & River Water & & PRWT \\
\hline 12 & Ground Water (Naun) & V.P.O-jol Lambri, Tehsil-Sujanpur, Distt-Hamirpur, H.P. & JLN \\
\hline 13 & River Water (Pung River) & Village-Chamiyola,P.O-Chauri, Tehsil-Sujanpur, Distt-Hamirpur, H.P. & KMPR \\
\hline 14 & River Water (Pung River) & Village-Chamiyola,P.O-Chauri, Tehsil-Sujanpur, Distt-Hamirpur, H.P. & KMPH \\
\hline 15 & Ground water & Gram panchyat - Kyarwan, Distt-Kangra & BJT \\
\hline 16 & Water Reservoir & Water Reservoir Sample, Ankleshwar, Gujarat & WR \\
\hline 17 & Tap Water & Tap Water, Axar Nagar, Bharuch, Gujarat & TW \\
\hline 18 & River Water & Narmada River sample near neelkanth mahadev temple, Bharuch Gujarat & NR \\
\hline 19 & River Water & Narmada River sample near Kabir Badd, Bharuch, Gujarat & KB \\
\hline 20 & Pond Water & Pond water sample collected from Village-Bhensali, BHARUCH, GUJARAT & BV \\
\hline 21 & Tap water & Ajamgarh, Lucknow & ATW \\
\hline 22 & Tap water & Jankipuram, Lucknow & JTW \\
\hline 23 & River Water & Allahabad & GR \\
\hline 24 & River Water & Lucknow & $\mathrm{GO}$ \\
\hline 25 & Tap water & Lucknow & $\mathrm{SN}$ \\
\hline 26 & Tap water & Lucknow & $\mathrm{GN}$ \\
\hline 27 & River Water & Lucknow & GHR \\
\hline 28 & Pond water & Lucknow & MP \\
\hline 29 & Pond water & Lucknow & MOL \\
\hline 30 & Pond water & Lucknow & $\mathrm{TP}$ \\
\hline
\end{tabular}

\section{Result and Discussion}

\subsection{Isolation of Vibrio spp. from water sample on TCBS media-}

Green colonies and yellow colonies of Vibrio organism were observed. On TCBS, yellow colonies were presumptively identified as $V$. alginolyticus, $V$. cholerae, and $V$. mimicus. Green or blue-green colonies were assumed to be $V$. parahaemolyticus, and V. vulnificus. A total of 22 water samples were found positive for Vibrio species out of 30 water sample.

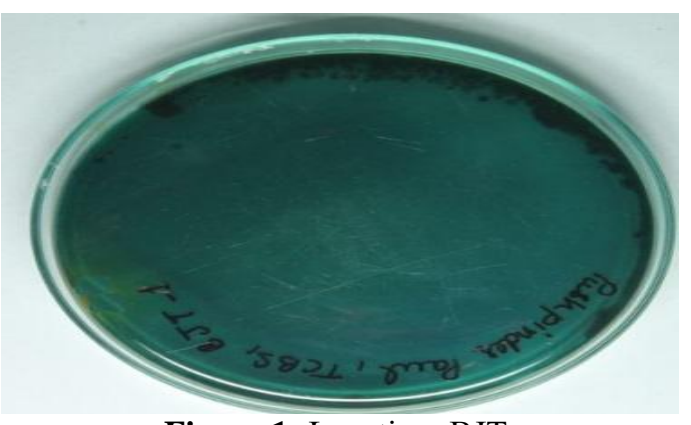

Figure 1: Location: BJT

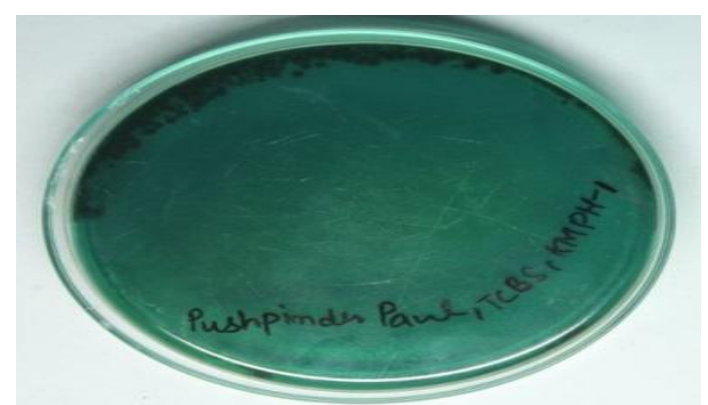

Figure 2: Location: KMPH

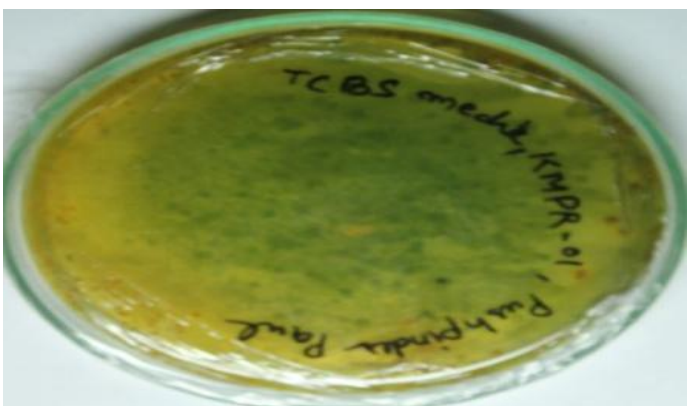

Figure 3: Location: KMPR 
International Journal of Science and Research (IJSR)

ISSN (Online): 2319-7064

Index Copernicus Value (2013): 6.14 | Impact Factor (2014): 5.611

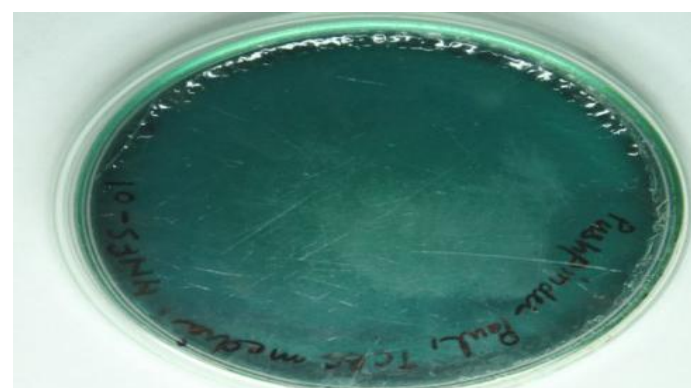

Figure 4: Location: NNFS

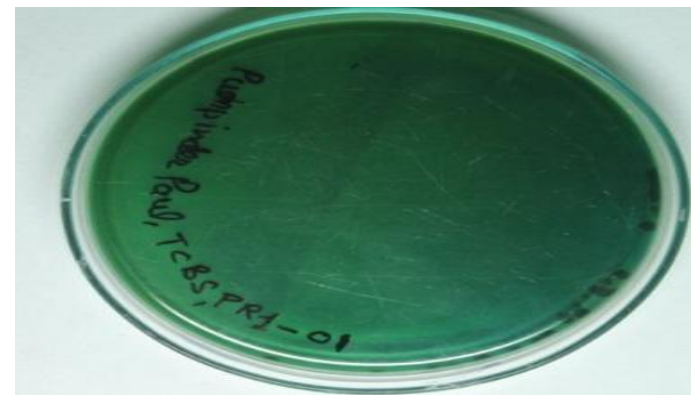

Figure 5: Location: PR1

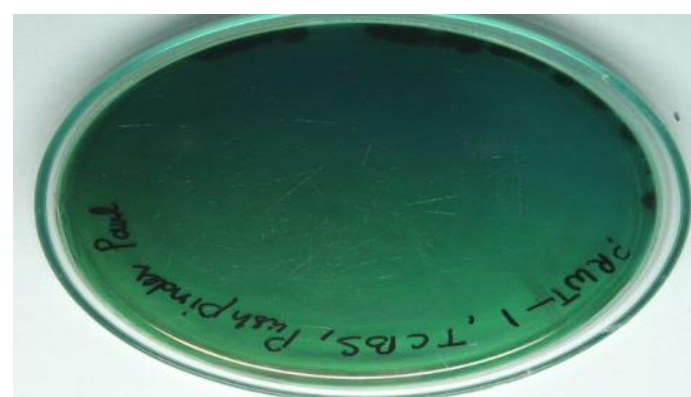

Figure 6: Location: PRWT

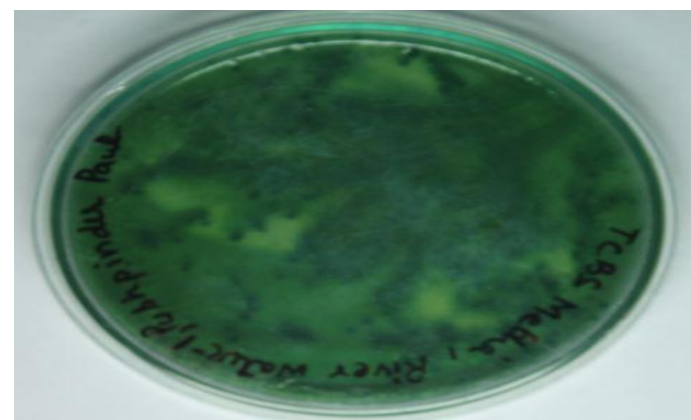

Figure 7: Location: R

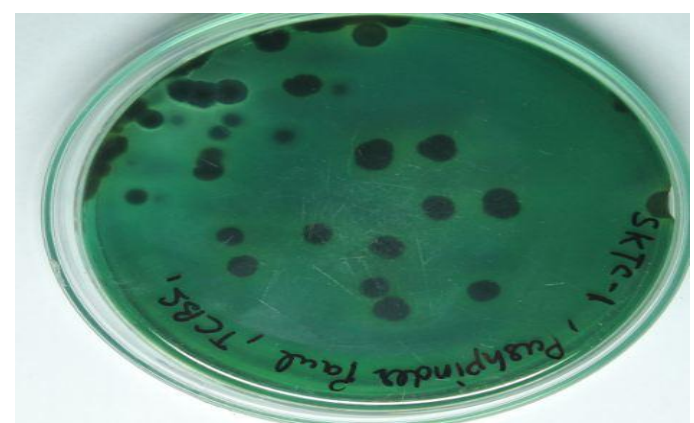

Figure 8: Location: SKTC

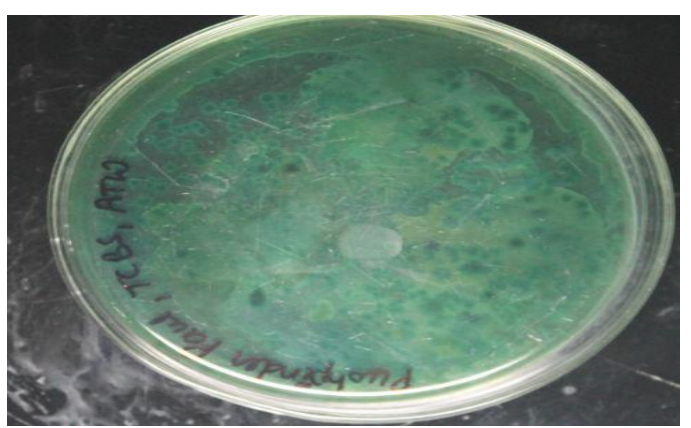

Figure 9: Location: ATW

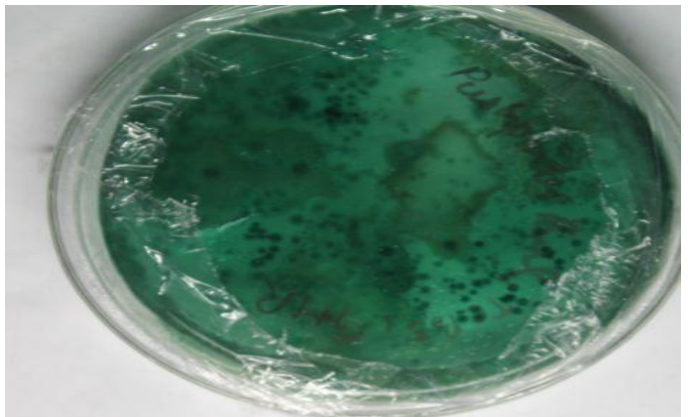

Figure 10: Location: GHR

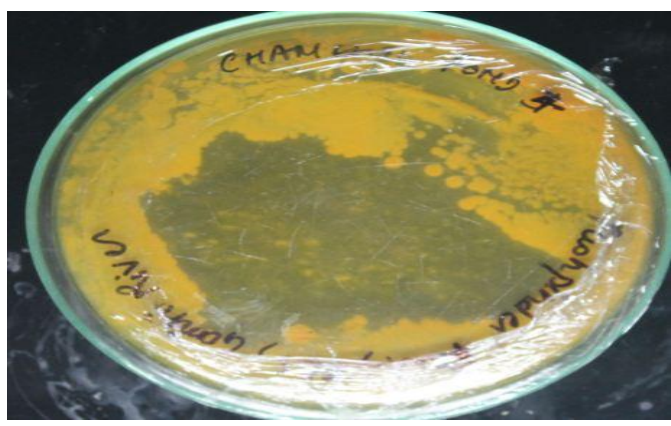

Figure 11: Location: $\mathrm{GO}$

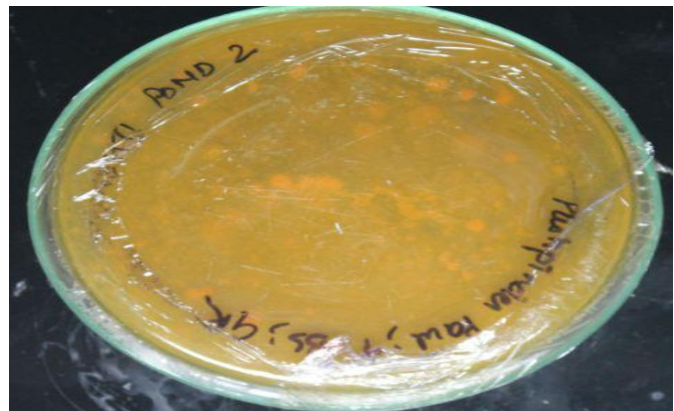

Figure 12: Location: GR

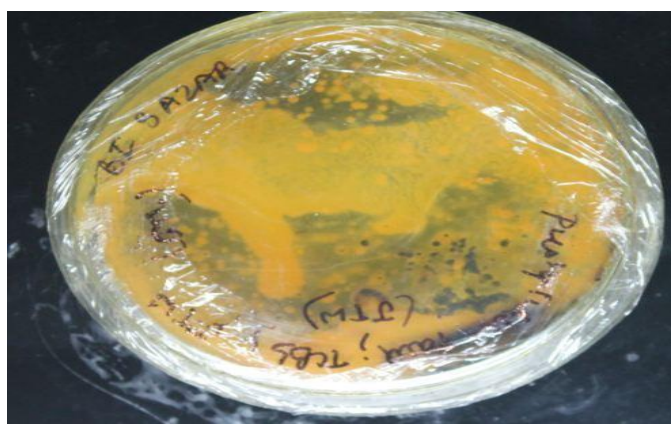

Figure 13: Location: GTW

Volume 5 Issue 3, March 2016 


\section{International Journal of Science and Research (IJSR) \\ ISSN (Online): 2319-7064}

Index Copernicus Value (2013): 6.14 | Impact Factor (2014): 5.611

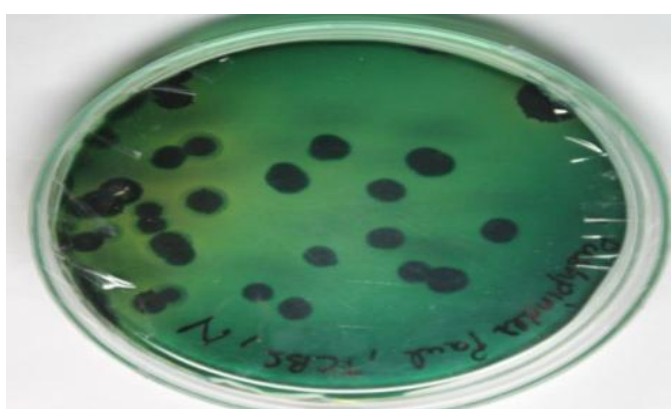

Figure 14: Location: $\mathrm{N}$

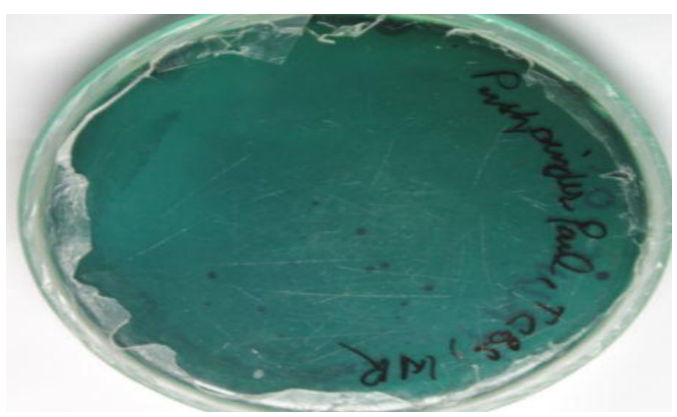

Figure 15: Location: WR

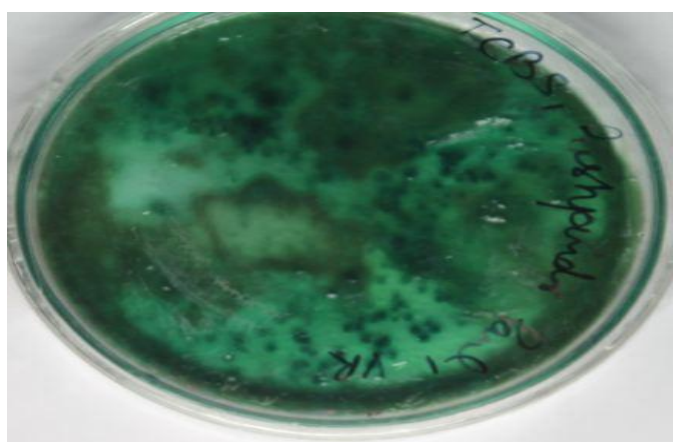

Figure 16: Location: VR

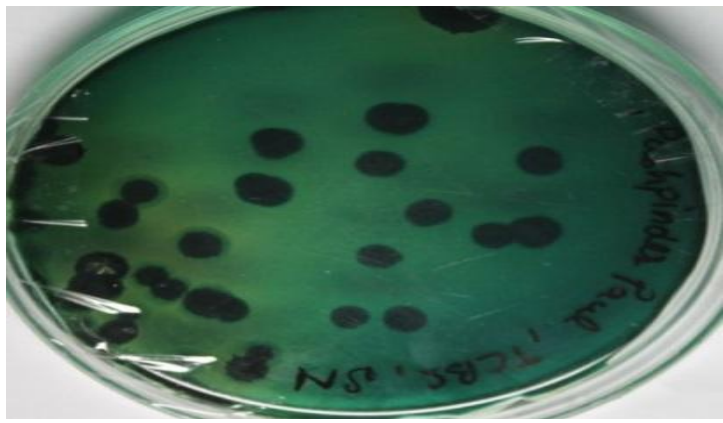

Figure 17: Location: SN

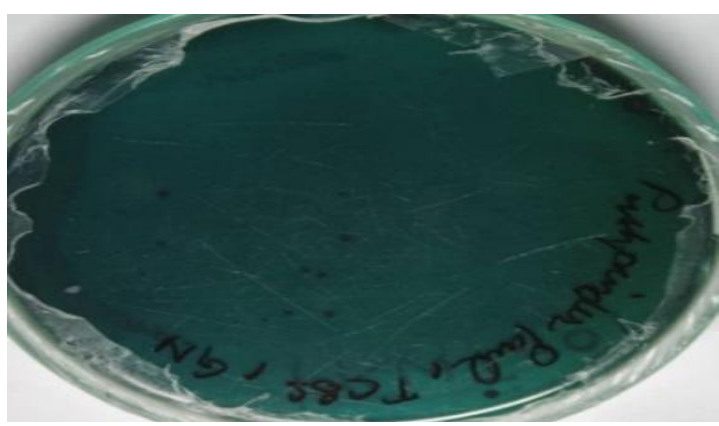

Figure 18: Location: GN

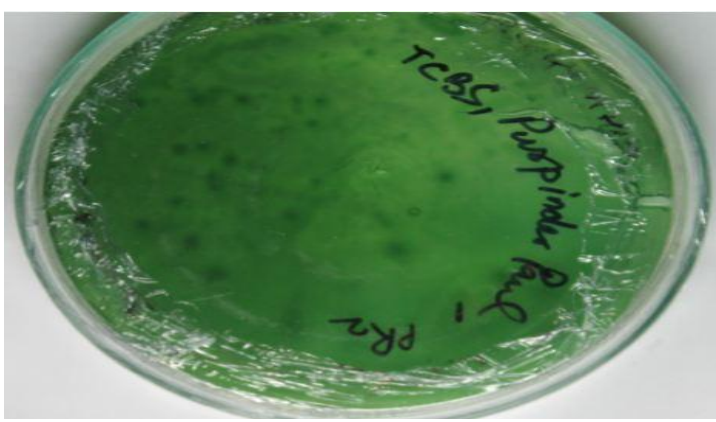

Figure 19: Location: PR2

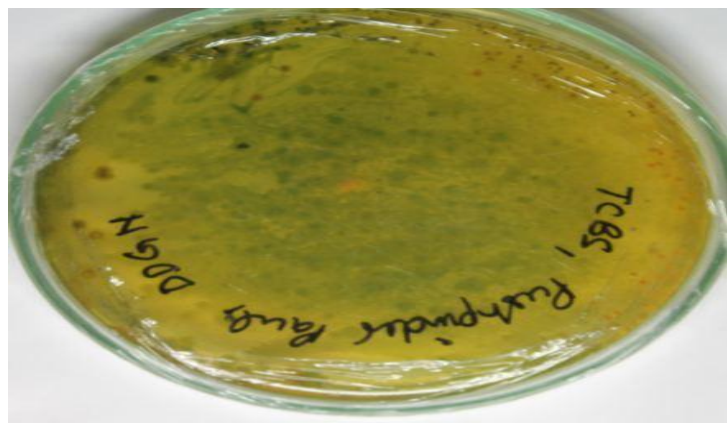

Figure 20: Location: DDGN

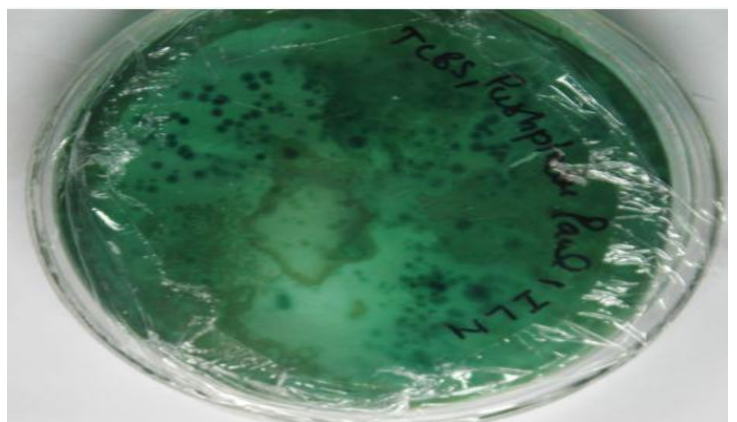

Figure 21: Location: ILN

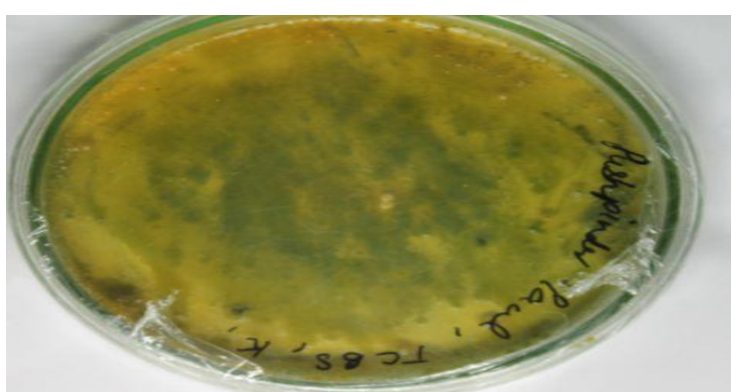

Figure 22: Location: $\mathrm{K}$

\section{Conclusions}

For identification of Vibrio species, we collected total 30 water samples from different locations of Himachal Pradesh, Gujarat and Uttar Pradesh. Our result showed that $73 \%$ of water samples $(\mathrm{n}=22)$ had the presence of Vibrio species whereas, $27 \%$ of water samples $(\mathrm{n}=08)$ showed negative i.e. absent of test organisms on TCBS Media. With respect to the observations made in the present study most literature reported a similar results [9] ranged fall between $21.4 \%-99.6 \%$ showed positive samples on TCBS agar plate media for Vibrio species.22 no samples were identified for the presence of Vibrio species contamination at different location. 


\section{References}

[1] Blackwell, K.D. and Oliver, J.D. (2008). The ecology of Vibrio vulnificus, Vibrio cholerae, and Vibrio parahaemolyticus in North Carolina estuaries. J Microbiol 46(2):146-53.

[2] Eiler, A., Gonzalez-Rey, C., Allen, S. and Bertilsson, $S$ (2007). Growth response of Vibrio cholerae and other Vibrio spp. to cyanobacterial dissolved organic matter and temperature in brackish water. FEMS Microbiol Ecol 60(3):4-8.

[3] Oliver, J.D., Warner, R.A., and Clel, D.R (1983). Distribution of Vibrio vulnificus and other lactosefermenting vibrios in the marine environment. Appl Environ Microbiol 45(3):85-98.

[4] Tamplin, M., Rodrick, G.E., Blake, N.J. and Cuba, T. (1982). Isolation and characterization of Vibrio vulnificus from two Florida estuaries. Appl Environ Microbiol 44 (6):66-70

[5] Tarr, C.L., Patel, J.S., Puhr, N.D., Sowers, E.G., Bopp, C.A. and Strockbine, N.A (2007). Identification of Vibrio isolates by a multiplex PCR assay and $r p o B$ sequence determination. $J$ Clin Microbiol 45(1):134e40.

[6] Morris, Jr, J.G (2003). Cholera and other types of vibriosis: a story of human pandemics and oysters on the half shell. Clin Infect Dis, 37(2):72-80.

[7] Farmer, J. J. I.,Janda, J. M., andBirkhead, K. M (2003). Vibrio, p. 706-718. In P. R. Murray (ed.), Manual of clinical microbiology, 8th ed. ASM Press, Washington, DC.

[8] Levinson, W., and Jawetz, E (1996).Medical Microbiology and Immunology, 4th ed. Appleton and Lange, U.S.A. pp 27-31, 103-5, 146.

[9] Gopal S, Otta SK ,Kumar S, Karunasagar I , Nishibuchi M, Karunasagar I (2005). The occurrence of Vibrio species in tropical shrimp culture environments; implications for food safety. International Journal of Food Microbiology, 102:151-159

\section{Author Profile}

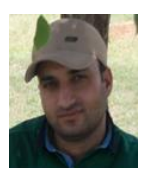

Pushpinder Paul received the M.Sc. degree in Biotechnology from Punjabi University, Patiala in 2008. From 2009 to till date he has worked with various pharmaceutical companies. His core area is sterile operations and validations. He is ISO 9001-2015 certified QMS Lead auditor from IRCA. He is PhD research scholar at Singhania University, Rajasthan. 